\title{
David Loewenstein. Treacherous Faith: The Specter of Heresy in Early Modern English Literature and Culture. Oxford: Oxford UP, 2013. xiv + 497 pp. ISBN 13: 9780199203390. \$99.00; $£ 65.00$ (cloth).
}

\section{DAVID L. SMITH}

This is an important, original and deeply researched book. David Loewenstein's purpose is to explore the ways in which early modern English authors constructed the phenomena of heretics and heresies, and the profound religious fears, fantasies and anxieties that shaped these constructions. In the process, he shows how concerns about heresies interacted with attitudes towards persecution, toleration and sectarianism. For readers of this journal, the last two chapters, devoted to Milton, are likely to be of greatest interest, but by locating Milton's writings within a long historical context dating back to the first half of the sixteenth century Loewenstein is able to demonstrate the extraordinary originality of Milton's approach to these issues. Indeed, Milton's reformulation of the categories of 'heresy' and 'sectary', and his closely related ideas of religious toleration and anti-formalism, are among this book's most significant findings.

Throughout, Loewenstein demonstrates an assured mastery of his material, and his argument is grounded in immensely wide reading in relevant primary sources, both manuscript and printed. These include not only a wide range of literary texts, pamphlets and polemical works but also 'proclamations; church documents; religious sermons and political tracts; martyrologies; heresiographies and anti-heresy tracts; and manuscripts and printed sources describing heresy trials and the frightening impact of heretics' (7). Loewenstein moves elegantly between detailed close readings of these texts and lively general arguments. He combines the literary scholar's attentiveness to language, voice and audience with the 
historian's sensitivity to political and religious contexts. He has triumphantly achieved his goal of writing a 'cross-disciplinary book' (1) and working as 'a literary historian' (7).

The book begins with a chapter on Thomas More, whom Loewenstein describes as 'the most formidable scourge of heretics in Tudor England' (11). This chapter successfully problematizes More by showing how this witty and urbane humanist harboured a 'terrifying obsession with heretics' that was 'fueled by a mixture of fear, paranoia, hatred, and a zealous desire to defend the old faith, preserve the purity and integrity of the Church, and resist religious change' (25). More's responses to heretics 'could be profoundly visceral and irrational', and the language and rhetoric that he used against them were 'sometimes terrifying in their virulence and lack of restraint' (29). More emerges from this chapter as 'a highly complex, contradictory, even unstable and schizophrenic writer whose heated religious imagination became unchecked' (30). The greater the threat that evangelicals seemed to pose during the late 1520 s and early 1530 s, the more vehemently More denounced them as heretics who were inconstant, unstable and manipulative. This ferocious campaign culminated in More's 'most ambitious piece of anti-evangelical polemic', his lengthy Confutation of Tyndale's Answer (1532-3), which represented heretics as 'diabolical, monstrous, and subhuman' $(54,56)$. In More's eyes, heresy was associated not only with treason and sedition but also with sinfulness, disease, sexual deviancy and monstrosity (63). That this 'supremely intelligent man and gifted writer' should also engage in a 'campaign of religious demonization and heresy-making' of such bitterness reveals More to be a 'richly complex writer with an ambiguous legacy' (68). Loewenstein's assessment is all the more convincing because it does not attempt to resolve the complexities and contradictions that lay deep within More's psyche.

The second chapter turns to the case of Anne Askew, a young woman who was tried, tortured and burnt for evangelical heresy in 1546. Loewenstein presents this as a moment of 
particular insecurity for the Henrician regime in which many of the King's more conservative counsellors (notably Norfolk, Rich, and Bishops Gardiner and Bonner) were seeking to curb the growth of sacramentarian heresy and to discredit their evangelical rivals at Court, who included Henry VIII's last Queen, Catherine Parr. Among the victims of this conservative reaction was Anne Askew, who uncompromisingly asserted 'the sufficient authority of Scripture' and the equality of men and women in understanding 'their faith by Bible reading and exposition' (97). This chapter charts her strategies for responding to her interrogators, and she emerges from the harrowing account of her torture and execution as a figure of remarkable intelligence and courage.

Loewenstein then examines John Foxe's Acts and Monuments, concentrating on the expanded and illustrated edition of 1570. This third chapter is excellent on Foxe's use of both language and visual images to construct a view of the Marian martyrs as mild and temperate victims. In the process, Foxe downplayed their diversity and aggressiveness: he presented them not as 'contentious religious radicals' but as 'mylde and constant Martyrs of Chryst' (118), and to that end his 'massive book is pervaded by powerful physical images and narratives of religious violence and sadistic cruelty' (115). Foxe's 'association of martyrdom with moderation is striking' (120), and he 'does all he can to persuade his readers that his godly martyrs are not dangerous early modern fundamentalists' (121). Some individuals, such as William Tyndale and Thomas Cranmer, could be absorbed within this construction of mild and moderate martyrdom more readily than other, more angular and combative personalities like John Hooper, who did not fit Foxe's paradigm at all comfortably. In particular, Loewenstein draws out the 'powerful tension in Foxe's writing' between his abhorrence of 'religious violence and savagery' and his 'strong sense of righteous anger' (155). 
The following chapter considers attitudes towards heresy in the later Elizabethan and Jacobean periods. Here Loewenstein focuses on four texts: Richard Bancroft's Sermon Preached at Paules Crosse (February 1589); Thomas Nashe's The Unfortunate Traveller (1594); Edmund Spenser's The Faerie Queene (1596); and James VI and I's Basilikon Doron (1599). The 1590s emerge from these works as a decade of considerable anxiety about heresy and radical separatism, insecurities that were closely linked to fears of social levelling and political subversion. Loewenstein argues that there were 'crucial connections and continuities' (187) in these religious fears and heresy-making between the sixteenth and seventeenth centuries, and he then moves in the second half of the book to consider the period from the 1640s to the early 1670s. This transition from Part I to Part II is perhaps a little abrupt, and the virtual absence of discussion of the later Jacobean and early Caroline periods has the effect of making the book slightly like a diptych.

That said, the second part of the book is if anything even more compelling than the first. Chapter Five analyses some of the leading heresiographers of the 1640s and 1650s, especially Presbyterians like Thomas Edwards who feared that England was descending into an abyss of religious separatism, heresy and political chaos. With Edwards's massive threepart work Gangraena (1646) we enter a nightmare world in which he attempted to itemise 'the great and seemingly growing multitude of heresies, errors, and sects' (198). Edwards deplored what he saw as 'a world of strange errours' (207) in which new heresies and sects abounded, promoting all manner of disorder, monstrosity, promiscuity and sexual licence. Gangraena offers a catalogue of horror stories, for example of soldiers urinating in fonts and sectaries baptising horses or pigs. Such fears help to explain why so many members of the Protectorate Parliaments abhorred the spread of errors, heresies and blasphemies, why they especially feared the Quakers, and why they demanded the savage corporal punishment of 
James Nayler, who had committed a public blasphemy in 1656 by re-enacting Christ's entry into Jerusalem on Palm Sunday.

Loewenstein then examines three writers who reacted strongly against these heresyhunters and instead advanced radical ideas of toleration: the Independent minister John Goodwin, the Leveller William Walwyn, and the religious pamphleteer Richard Overton who later also became a Leveller. All three writers bitterly attacked those, like Edwards, who sought to restrict the consciences of others. Their deeply anti-authoritarian stance also provides an important context for understanding Milton's Areopagitica (November 1644) in which he mocked the heresy-hunters, with their 'fantastic terrors of sect and schism' (204; Loewenstein's emphasis). In his passionate defence of individual conscience and the need for an open-ended exploration of religious issues, Milton was very much in accord with Goodwin, Walwyn and Overton.

This discussion leads naturally into Chapters Seven and Eight which deal, respectively, with Milton's prose polemics and with Paradise Lost. Chapter Seven begins with a masterly analysis of Milton's 1646 sonnet 'On the New Forcers of Conscience under the Long Parliament' (267-70), in which he denounced heresy-hunters like 'Shallow Edwards' and lamented that 'New Presbyter is but Old Priest writ Large' (268). Loewenstein argues perceptively that 'its controlled fury gives the poem its exceptional power as it expresses Milton's artful response to the demonization and making of heretics during the English Revolution' (271). Loewenstein then traces the development of Milton's thought on the subjects of heresy and toleration, beginning with the early pamphlet The Reason of Church-Government (February 1642). There is a splendid section on Areopagitica (274-82) which, according to Loewenstein, 'conveys, more vividly that any other piece of writing from the period, the sheer verbal energy, ferment, and proliferation of ideas unleashed by the upheavals of the English Revolution' (274). Here we see Milton's remarkably original 
reformulation of what it meant to be a heretic: 'A man may be a heretick in the truth; and if he beleeve things only because his Pastor says so, or the Assembly so determins, without knowing other reason, though his belief be true, yet the very truth he holds, becomes his heresie' (275). Thus, in Loewenstein's words, 'the greatest heresy is not religious division but the static, unexamined, and, consequently, often dogmatic, rigid possession of religious truths' (277). Milton returned to these issues in his Treatise of Civil Power in Ecclesiastical Causes (February 1659): here he expressed his deepening anti-formalism together with his steadfast conviction that we ought 'to believe what in our conscience we apprehend the scripture to say, though the visible church with all her doctors gainsay' (285; Loewenstein's emphasis). Milton extended this point further in his last major tract, Of True Religion, Haeresie, Schisme, Toleration (May 1673), where he advanced a strikingly fresh and original definition of 'sectary': 'Sects may be in a true Church as well as in a false, when men follow the Doctrin too much for the Teachers sake, whom they think almost infallible; and this becomes, through Infirmity, implicit Faith; and the name Sectary, pertains to such a Disciple' (289; Loewenstein's emphasis). Milton thus redefined 'sectary', like 'heretic', in such a way as to assert that the greatest danger was to behave with servility towards those figures in authority who were deemed to be infallible.

This account of the development of Milton's thought provides the context for the rich and rewarding discussion of Paradise Lost in Chapter Eight. Loewenstein argues that this great epic poem engaged deeply with the issues of heresy, blasphemy and toleration that had been central to Milton's concerns since the early 1640s. Milton 'gives Satan qualities orthodox godly observers and seventeenth-century heresiographers used to construct the cunning behaviour, motives, and rhetoric of hatred of wilful, treacherous heretics' (307). Within anti-heretical literature, heretics were often portrayed as practising the arts of cunning and dissimulation, and of deploying subtle, seductive and manipulative techniques to beguile 
the unwary. Loewenstein suggests that in Paradise Lost, Milton 'dramatizes with great intensity the terrifying offense of blasphemy as a speech act' (329) in two key episodes: the debate between God the Father and his Son in Book 3, and Satan's attempt to foment schism in Book 5 (330-3). Milton's sympathies were evident in the fact that it is the lone dissenter who rejects Satan's arguments in favour of schism and who remains 'unseduc'd' and 'unmov'd' by his blasphemous words. Milton thus forced his readers to reconsider the nature of blasphemy by portraying it not as an assault upon an orthodox ministry but rather as 'scorning the unorthodox Godhead and the newly anointed Messiah whose authority, justified by merit more than anything else, the restless adversary deeply disdains and reviles' (340). The poem 'seems pessimistic about the prospects of religious toleration in a postlapsarian world frequently blighted by political tyranny and "heavy persecution"” (342), but Milton nevertheless stressed, as in his other writings, the importance of spontaneous worship and liberty of conscience rather than conformity to the authority of a national Church. Loewenstein argues persuasively that the poem's 'grappling with religious liberty, as well as a radical spirituality free from any form of outward constraint and established public worship, places' it in 'the midst of early modern contentions about toleration in relation to religious uniformity', and that it expressed Milton's 'defiant alignment with liberty of conscience' (343). In this way, Milton was at pains to distinguish between 'demonically-inspired rebellion and blasphemy on the one hand' and religious separatism and liberty of conscience in religion on the other, 'and indeed to question the easy or automatic conflation of these categories' (344). This final chapter thus ties together the themes of the book by demonstrating the boldness and originality of Milton's stance on the issues of heresy, blasphemy and toleration.

Overall, this is a book of profound learning and powerful argument. It reveals the complex blend of change and continuity that characterised English ideas about heresy from 
the reign of Henry VIII to that of Charles II. The book is very accurate and I detected virtually no factual slips, although it is worth noting that Whitgift was Archbishop of Canterbury until 1604 rather than 1603 (164), and that whilst Nayler's health was indeed broken by his punishment and imprisonment, the immediate cause of his death was an attack by robbers as he was making his way northwards after his release (234). But these are very minor points compared with Loewenstein's achievement in reconstructing 'the complex ways that religious fears, heresy-making, and the literary imagination interacted in the early modern period and were politicized' (348). He has recovered the 'dark fantasies, anxieties, terrors, and violence' that the 'heresy-making imagination' generated, together with 'the ways the fearsome specter of heresy could stimulate the literary creativity of early modern authors engaging with it from diverse religious and political perspectives' (348). Above all, for its acute analysis of the construction of heresy, for its exploration of the dynamics and language of fear, and for its fresh contextualisation and interpretation of Milton's writings, this book will be essential reading for literary scholars and historians of early modern England. 